\begin{tabular}{|c|c|c|}
\hline \multirow[b]{2}{*}{ TI } & Int.J.Curr.Microbiol.App.Sci (2021) 10(09): 464-472 & \\
\hline & $\begin{array}{l}\text { International Journal of Current Microbiology and Applied Sciences } \\
\text { ISSN: 2319-7706 Volume } 10 \text { Number } 09 \text { (2021) } \\
\text { Journal homepage: http://www.ijcmas.com }\end{array}$ & 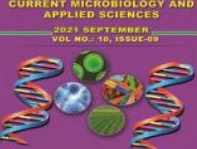 \\
\hline PUBLISHERS & & \\
\hline
\end{tabular}

\title{
Change of Land Quality with the Introduction of the Biochar Combination and Cocoa Waste Compost
}

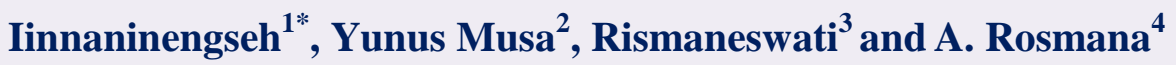 \\ ${ }^{1}$ Postgraduate School Hasanuddin University, Makassar, South Sulawesi, Indonesia \\ ${ }^{2}$ Department of Agrotechnology, ${ }^{3}$ Department of Soil Science, \\ ${ }^{4}$ Department of Pest and Diseases, Hasanuddin University, Makassar, \\ South Sulawesi, Indonesia \\ *Corresponding author
}

\section{A B S T R A C T}

Keywords

Cocoa husk biochar, fermented cocoa leaf waste

Article Info

Accepted:

15 August 2021

Available Online:

10 September 2021
This study examines the introduction of a combination of cocoa husk biochar which has been a cocoa plantation waste combined with fermented cocoa leaf waste. This study was conducted in West Sulawesi. This study used a randomized block design using a factorial model where the first factor was the administration of cocoa husk biochar with 3 levels, namely without administration (B0), $6 \mathrm{~kg}$ plant biochar $^{-1}$ (B1), $12 \mathrm{~kg}$ plant $\operatorname{biochar}^{-1}$ (B2) while the second factor was application of fermented cocoa leaf waste $(\mathrm{K})$ which consists of 3 levels, namely without giving cocoa leaf waste (K0), giving $6 \mathrm{~kg} \mathrm{plant}^{-1}(\mathrm{~K} 1)$, biochar $12 \mathrm{~kg}$ plant ${ }^{1}$ (K2). The nine treatment combinations were repeated three times to obtain 27 plant samples. The analysed soil characteristics are calcium $(\mathrm{Ca})$, magnesium $(\mathrm{Mg})$ and potassium $(\mathrm{K})$ showed that the combination of cocoa rind Biochar and fermented cocoa leaf waste had an effect on increasing calcium (Ca) by 9.23. Magnesium 1.66 and for the element Potassium had no significant effect on the interaction of the combination of cocoa husk biochar and fermented cocoa leaf waste, but gave a very significant effect on the administration of biochar $12 \mathrm{~kg}$ plants $^{-1}$.

\section{Introduction}

Cocoa (Theobroma cacao L) plantation is an agricultural sector that has long been known and occupied by most people in rural areas. Since the first time the cocoa commodity entered Indonesia, cocoa plants from South America have been very adaptable, taking shelter among large trees. The ease with which this commodity is accepted by the community as a plantation crop is due to the fact that cacao is easy to adapt to shade conditions 
between large trees, although it does not like shade, both cocoa is economically very fast in producing so that farmers can easily get income compared to other plantation hard plants, third in terms of lower prices.

Cocoa commodities tend to have relatively high prices and these four commodities do not require too complicated technology in their cultivation. Until now, this commodity is the third foreign exchange earner after rubber and palm oil.

Several break throughs and technologies have been given to improve the management of the cultivation of this commodity and so far have proven enough and have been widely applied and developed among farmers. However, it should be realized that the land used is still the same which of course has undergone many changes, especially in terms of changes in soil quality.

The application of organic matter on land is still considered beneficial in terms of quality with the application of other additives so that various studies are more directed at how these additives are able to bring farmers closer to nature which provides convenience in improving land quality.

Decrease in land quality or soil fertility can be caused by uptake of nutrients by plants and secondly loss of nutrients by leaching (soil erosion) and without a balanced return in the form of fertilization on the soil and other cultivation applications such as proper maintenance.

In Indonesia, which is a tropical country, the rate of decomposition (weathering) of organic matter is high so that the natural organic soil improvement materials used are more temporary (Neneng laela Nurida, 2014; Neneng Laela Nurida, 2017), besides that the rate of land degradation also plays a role in soil damage (Alibasyah \& Karim, 2013).
Biochar is a solid carbon material that is the result of conversion from organic waste (agricultural biomass) obtained through incomplete combustion or with a less limited oxygen supply so that the results are obtained in the form of biochar containing carbon that can be applied which is useful as a soil enhancer.

The application of biochar to agricultural land (dry and wet land) can increase the ability of the soil to store water and nutrients, improve soil looseness so as to stimulate and create a good habitat for good symbiotic microorganisms to breed, able to suppress the proliferation of diseases caused by soil pathogens.

The best source of biochar raw material is organic waste, especially agricultural waste. The potential for biochar raw materials is quite abundant, namely in the form of agricultural waste that is difficult to decompose or with a high $\mathrm{C} / \mathrm{N}$ ratio $(\mathrm{N} \mathrm{L}$ Nurida \& Sutono, 2012). Cocoa husk itself has a fairly high waste potential, about $75 \%$ of a whole cocoa fruit is in the form of fruit skin, while the cocoa beans occupy as much as $23 \%$ and the placenta itself is $2 \%$ (Kamelia \& Fathurohman, 2017).

Indonesia itself has a very large potential for using biochar considering that the raw materials for this are very abundant and easy to obtain. Organic materials such as coconut shells, cocoa husks, rice husks, oil palm empty fruit bunches, corn cobs and some ingredients other types are plentiful and underutilized.

Several research results show that the proportion of rice husks is $16-28 \%$ of the total dry milled grain; the proportion of coconut shells is $15-19 \%$; the proportion of oil palm shells is $6.4 \%$ of the fresh fruit bunches production, and also corn has $21 \%$ of the dry cob weight (Neneng laela Nurida, 2014). 


\section{Materials and Methods}

\section{Research Location and Design}

This research was conducted in Batetangnga Village, Binuang District, Polewali Mandar Regency with a duration of activity of approximately 8 months. Soil analysis was carried out at the Soil Laboratory of the Department of Soil Science, Faculty of Agriculture, Hasanuddin University. The material used as the object of research is soil on community cocoa plantations while the tools used for soil sampling are soil drill with a depth of $40 \mathrm{~cm}$, paper bag, meter, machete, knife, shovel sieve, plastic sample, camera label paper and stationery. Sampling of soil samples for analysis of soil chemical properties was carried out by taking soil samples from the soil as deep as the tillage layer $(40 \mathrm{~cm})$. A soil drill is used so that the soil can be reached up to the desired layer.

This study used a randomized block design using a factorial model where the first factor was the provision of cocoa husk biochar with 3 (three) levels, namely without giving (B0), biochar $6 \mathrm{~kg}$ plant $^{-1}$ (B1), biochar $12 \mathrm{~kg} \mathrm{plant}^{-1}$ (B2) while the second factor is the application of fermented cocoa leaf waste $(\mathrm{K})$ which consists of 3 (three) levels, namely without giving cocoa leaf waste (K0), giving $6 \mathrm{~kg}$ plant $^{-1}(\mathrm{~K} 1)$, biochar $12 \mathrm{~kg}$ plant $^{-1}(\mathrm{~K} 2)$. With nine treatment combinations repeated 3 (three) times to obtain 27 Data analysis Soil samples were tested in the Soil Laboratory of Hasanuddin University Makassar, by analyzing several soil micro nutrients $(\mathrm{Ca}$, $\mathrm{Mg}, \mathrm{Na}$ and $\mathrm{K}$ ) and also the value of soil cation exchange capacity (CEC). Soil analysis data was processed using Microsoft office, while biochar and compost analysis data were processed using SPSS for windows 21. To assess the relationship between the provision of biochar and compost to changes in the micronutrient content of cocoa plantation soil.

\section{Results and Discussion}

Determining the quality of the soil has many assumptions, in addition to the texture of the structure as well as the chemical properties contained in the soil. Soil is an intermediary provider of factors for plant growth. Several parameters for determining soil quality can be measured and calculated in order to get a further picture of soil conditions between degrees of acidity, analysis of cation exchange capacity, Phosphorus, Nitrogen, Potassium Magnesium and Calcium(Rafeie Jahed et al., 2014). The last three elements are the elements that are widely reviewed in the soil. These elements interact with each other, one of the higher elements can have an influence on other elements even for plant growth can also disrupt plant growth and production.

According to Table 1, the soil of the study site is classified as acidic with a $\mathrm{pH}$ of 5.6 this area is the location of smallholder plantations in mountainous areas and poor in nutrients, soil $\mathrm{pH}$ indicates the degree of acidity or balance between the concentrations of $\mathrm{H}+$ and $\mathrm{OH}$ in the soil solution atmosphere. If the concentration of $\mathrm{H}+$ in the soil solution is more than $\mathrm{OH}$, then the atmosphere of the soil solution becomes acidic, conversely if the concentration of $\mathrm{OH}$ - is more than $\mathrm{H}+$, the soil solution will become alkaline (Winarso, 2005).

The condition of the low organic C content, which is around 1.92, could have been caused by leaching and also erosion from the plantation area. Facing this, it is necessary to use soil enhancer materials that are easily obtained so as to increase the ability of the soil to hold nutrients as well as improve other soil properties. Low organic matter content results in a lack of support and efficient use of fertilizers and a reduction in some nutrients from the root environment (Juarsah et al., 2009). Organic matter for the soil is the main 
source of macronutrients as well as soil micronutrients, along with soil particles. Together with soil particles, in the process of erosion by water carried by soil organic matter also, which actually has an important function in agricultural cultivation. Organic matter is part of an ecosystem that is closely related to the biological state of the soil, physical and chemical properties (Six et al., 2004).

The total $\mathrm{N}$ content of the research site soil is classified as very low to low $(0.05-0.19 \%)$. Total $\mathrm{N}$ is obtained from the weathering of a number of dissolved organic matter from the decomposition process. Meanwhile, a number of organic materials at the research site are in the form of coarse which have low $\mathrm{N}$ levels with low $\mathrm{C} / \mathrm{N}$ ratio. Several things that affect the destruction of organic matter are temperature, soil processing methods in this case plant cultivation activities, humidity of the planting area, including soil $\mathrm{pH}$ and also the type of organic matter around the area.

Meanwhile, the initial sodium (Na) value before treatment was $0.19 \mathrm{me} / 100 \mathrm{~g}$ which was relatively low. Sodium is a micronutrient that is absorbed by plants in the form of $\mathrm{Na}+$ although this condition in general will not affect plant growth because $\mathrm{Na}$ is not an essential element, in which case if $\mathrm{Na}$ in the soil is high, it will increase the osmosis value so that it leads to the emergence of a plasmolysis effect.

The presence of high $\mathrm{Na}$ in the soil also gives a bad influence on the damage to the soil structure (sodic) so that it can make the soil solid.

The initial analysis of soil CEC the study was $26.32 \mathrm{me} / 100 \mathrm{~g}$ including the high category. Cation exchange capacity (CEC) is a chemical property of soil that is closely related to soil fertility. If the soil has a high CEC value, then the soil should be able to provide and absorb nutrients better than the soil with a low CEC value. However, this comes back again to the local location because the nutrients available and can be absorbed by plants also depend on the local topography and climate conditions as well as the Base Saturation (KB) at a low location of $27 \%$ which is closely related to a low soil pH of 5.6 slightly acidic so that potentially $\mathrm{Al}$ and $\mathrm{Fe}$ elements will be absorbed in the soil difficult to reuse.

Cation exchange capacity is the ability of soil colloids to adsorb, attract exchange cations such as $\mathrm{K}+, \mathrm{Mg} 2+, \mathrm{Na}+, \mathrm{Ca} 2+, \mathrm{Al} 3+$. (high base saturation) So that if the cation exchange capacity is high, in general this condition is able to increase soil fertility. The results showed that there was a significant change by giving $12 \mathrm{~kg}$ of cocoa husk biochar ${ }^{-1}$ and $12 \mathrm{~kg}$ of fermented cocoa leaf waste compost of $28.47 \mathrm{me} / 100 \mathrm{~g}$ from the initial condition without treatment combination (control) of 19 , $99 \mathrm{me} / 100 \mathrm{~g}$. This increase was followed by an increase in the nutrient Calcium $(\mathrm{Ca})$ in the same treatment of $9.23 \mathrm{me} / 100 \mathrm{~g}$ from 4.55 $\mathrm{me} / 100 \mathrm{~g}$ in the control. This is in line with the opinion (Basir et al., 2016)There was an increase in CEC due to the provision of biochar as well as a decrease in $\mathrm{pH}$ to neutral.

\section{The relationship between the provision of Biochar and cocoa leaf waste on the dynamics of the nutrient Calcium (Ca)}

The results of the initial observation of the research site showed Calcium 4.52 me / $100 \mathrm{~g}$, all included in the medium category. Calcium is an important element in plant metabolism, regulates the osmotic pressure of cell sap so that if this element is lacking in plant absorption, it can cause symptoms of abnormalities in the plant growth process, such as disturbances in the flowering process.

Furthermore, the role of other elements of Calcium (Ca) in plants is very dominant, 
especially at points of plant growth such as root elongation and the process of opening new shoots so that if the amount of calcium in the soil is sufficient, plants can also grow optimally.
After application there was an increase in the value of Calcium in the combination treatment of compost and biochar of $12 \mathrm{~kg} \mathrm{plant}^{-1}$, which increased almost $50 \%$ from the treatment of biochar $6 \mathrm{~kg}$ plant $^{-1}$ and cocoa waste compost as much as $12 \mathrm{~kg} \mathrm{plant}^{-1}$.

Table.1 Analysis of initial soil data Research location

\begin{tabular}{|c|c|c|}
\hline S.No & Soil properties & Value \\
\hline $\mathbf{1}$ & $\mathrm{C}(\%)$ & 1,92 \\
\hline $\mathbf{2}$ & $\mathrm{N}(\%)$ & 0,14 \\
\hline $\mathbf{3}$ & $\mathrm{P}_{2} \mathrm{O}_{5} \mathrm{Olasen}(\mathrm{ppm})$ & 7,6 \\
\hline $\mathbf{4}$ & $\mathrm{CEC}(\mathrm{me} / 100 \mathrm{~g})$ & 26,32 \\
\hline $\mathbf{5}$ & $\mathrm{pH} \mathrm{H}_{2} \mathrm{O}$ & 5,6 \\
\hline $\mathbf{6}$ & Cation Exchange $\mathrm{Rate}\left(\mathrm{NH}_{4}-\right.$ Asetat $\left.1 \mathrm{~N}, \mathrm{pH} 7\right) \mathrm{K}(\mathrm{me}$ & 0,41 \\
\hline $\mathbf{7}$ & $/ 100 \mathrm{~g})$ & \\
\hline $\mathbf{8}$ & $\mathrm{Na}(\mathrm{me} / 100 \mathrm{~g})$ & 0,19 \\
\hline $\mathbf{9}$ & $\mathrm{Mg}(\mathrm{me} / 100 \mathrm{~g})$ & 1,98 \\
\hline $\mathbf{1 0}$ & $\mathrm{Ca}(\mathrm{me} / 100 \mathrm{~g})$ & 4,52 \\
\hline $\mathbf{1 1}$ & $\mathrm{K}(\mathrm{me} / 100 \mathrm{~g})$ & 0,16 \\
\hline
\end{tabular}

Table.2 Results of Analysis of CEC Caution Exchange Capacity in the soil of the root area with the provision of cocoa husk Biochar and fermented cocoa leaf waste.

\begin{tabular}{|c|c|c|c|}
\hline \multirow{2}{*}{$\begin{array}{l}\text { Provision of Cocoa husk } \\
\left.\text { Biochar (kg plant }{ }^{-1}\right)\end{array}$} & \multicolumn{3}{|c|}{ Fermented cocoa leaf waste $\left(\mathrm{kg} \mathrm{plant}^{-1}\right)$} \\
\hline & $0(\mathrm{~K} 0)$ & $6(\mathrm{~K} 1)$ & $12(\mathrm{~K} 2)$ \\
\hline $\mathbf{0}(\mathbf{B o})$ & $19.99^{\mathrm{a}}$ & $20.45^{\mathrm{ab}}$ & $20.45^{\mathrm{ab}}$ \\
\hline 6 (B1) & $21.52^{\mathrm{ab}}$ & $24.88^{\mathrm{b}}$ & $25.57^{\mathbf{b}}$ \\
\hline 12 (B2) & $21.22^{\mathrm{ab}}$ & $25.53^{\mathrm{b}}$ & $28.47^{\mathrm{c}}$ \\
\hline
\end{tabular}

Note: The numbers followed by the same letter show that they are not significantly different according to Tukey's follow-up test at the 0.01 level.

Table.3 Results of Calcium Analysis in the soil of the root area with the provision of Cocoa Skin Biochar and Cocoa Leaf Compost.

\begin{tabular}{|c|c|c|c|}
\hline $\begin{array}{c}\text { Provision of Cocoa Shell Biochar } \\
\left.\text { (kg plant }^{-1}\right)\end{array}$ & \multicolumn{3}{|c|}{ Compost Cocoa leaf waste (kg plant $^{-\mathbf{l}}$ ) } \\
\cline { 2 - 4 } & $0(\mathrm{~K} 0)$ & $6(\mathrm{~K} 1)$ & $12(\mathrm{~K} 2)$ \\
\hline $\mathbf{0}(\mathbf{B o})$ & $4.55^{\mathrm{a}}$ & $5.46^{\mathrm{c}}$ & $5.11^{\mathrm{b}}$ \\
\hline $\mathbf{6}(\mathbf{B} 1)$ & $5.03^{\mathrm{b}}$ & $5.80^{\mathrm{c}}$ & $6.86^{\mathrm{d}}$ \\
\hline $\mathbf{1 2}(\mathbf{B} 2)$ & $5.97^{\mathrm{c}}$ & $7.02^{\mathrm{d}}$ & $9.23^{\mathrm{d}}$ \\
\hline
\end{tabular}

Note: The numbers followed by the same letter show that they are not significantly different according to Tukey's follow-up test at the level of 0.01 
Table.4 Results of Magnesium Analysis in the soil of the root area by giving Biochar cocoa husk and Cocoa leaf compost.

\begin{tabular}{|c|c|c|c|}
\hline \multirow{2}{*}{$\begin{array}{c}\text { Provision of Cocoa Shell } \\
\text { Biochar (kg plant-1) }\end{array}$} & \multicolumn{3}{|c|}{ Compost Cocoa leaf waste (kg plant ${ }^{-\boldsymbol{I}}$ ) } \\
\cline { 2 - 4 }$(\mathbf{k}$ (K0) & $6(\mathrm{~K} 1)$ & $12(\mathrm{~K} 2)$ \\
\hline $\mathbf{0}$ (Bo) & $2.84^{\mathrm{b}}$ & $1.24^{\mathrm{a}}$ & $1.26^{\mathrm{a}}$ \\
\hline $\mathbf{6}$ (B1) & $0.56^{\mathrm{a}}$ & $1.53^{\mathrm{a}}$ & $1.54^{\mathrm{a}}$ \\
\hline $\mathbf{1 2}(\mathrm{B} 2)$ & $1.59^{\mathrm{a}}$ & $1.06^{\mathrm{a}}$ & $1.66^{\mathrm{a}}$ \\
\hline
\end{tabular}

Note: The numbers followed by the same letter show that they are not significantly different according to Tukey's follow-up test at the level of 0.01

Table.5 Results of Potassium analysis in the soil of the root area with the provision of Cocoa

Skin Biochar and Cocoa Leaf Compost.

\begin{tabular}{|c|c|c|c|}
\hline \multirow{2}{*}{$\begin{array}{l}\text { Provision of Cocoa Shell } \\
\text { Biochar }\left(\mathrm{kg} \mathrm{plant}^{-1}\right)\end{array}$} & \multicolumn{3}{|c|}{ Compost Cocoa leaf waste $\left(\mathrm{kg} \mathrm{plant}^{-1}\right)$} \\
\hline & $0(\mathrm{~K} 0)$ & $6(\mathrm{~K} 1)$ & $12(\mathrm{~K} 2)$ \\
\hline $\mathbf{0}(\mathbf{B o})$ & $0.16^{\mathrm{a}}$ & $0.21^{\mathrm{a}}$ & $0.29^{b}$ \\
\hline 6 (B1) & $0.28^{\mathrm{b}}$ & $0.27^{\mathrm{b}}$ & $0.31^{\mathrm{ab}}$ \\
\hline 12 (B2) & $0.26^{\mathrm{a}}$ & $0.25^{\mathrm{a}}$ & $0.27^{b}$ \\
\hline
\end{tabular}

Note: The numbers followed by the same letter show that they are not significantly different according to Tukey's follow-up test at a level of 0.05

Table.6

\begin{tabular}{|c|c|c|c|c|c|}
\hline \multicolumn{6}{|c|}{$\mathbf{P}_{2} \mathrm{O}_{5}$} \\
\hline & \multirow[t]{2}{*}{ Biochar } & \multirow[t]{2}{*}{$\mathrm{N}$} & \multicolumn{3}{|c|}{ Subset } \\
\hline & & & 1 & 2 & 3 \\
\hline \multirow[t]{4}{*}{ Tukey HSD ${ }^{a, b}$} & B0 & 9 & $14.0244^{\mathrm{a}}$ & & \\
\hline & B1 & 9 & & $17.7767^{b}$ & \\
\hline & $\mathrm{B} 2$ & 9 & & & $19.6444^{\mathrm{c}}$ \\
\hline & Sig. & & 1.000 & 1.000 & 1.000 \\
\hline \multicolumn{6}{|c|}{$\begin{array}{l}\text { Means for groups in homogeneous subsets are displayed. } \\
\text { Based on observed means. } \\
\text { The error term is Mean Square(Error) }=1,458 \text {. }\end{array}$} \\
\hline \multicolumn{6}{|c|}{ a. Uses Harmonic Mean Sample Size $=9,000$} \\
\hline b. Alpha $=0.05$ & & & & & \\
\hline
\end{tabular}

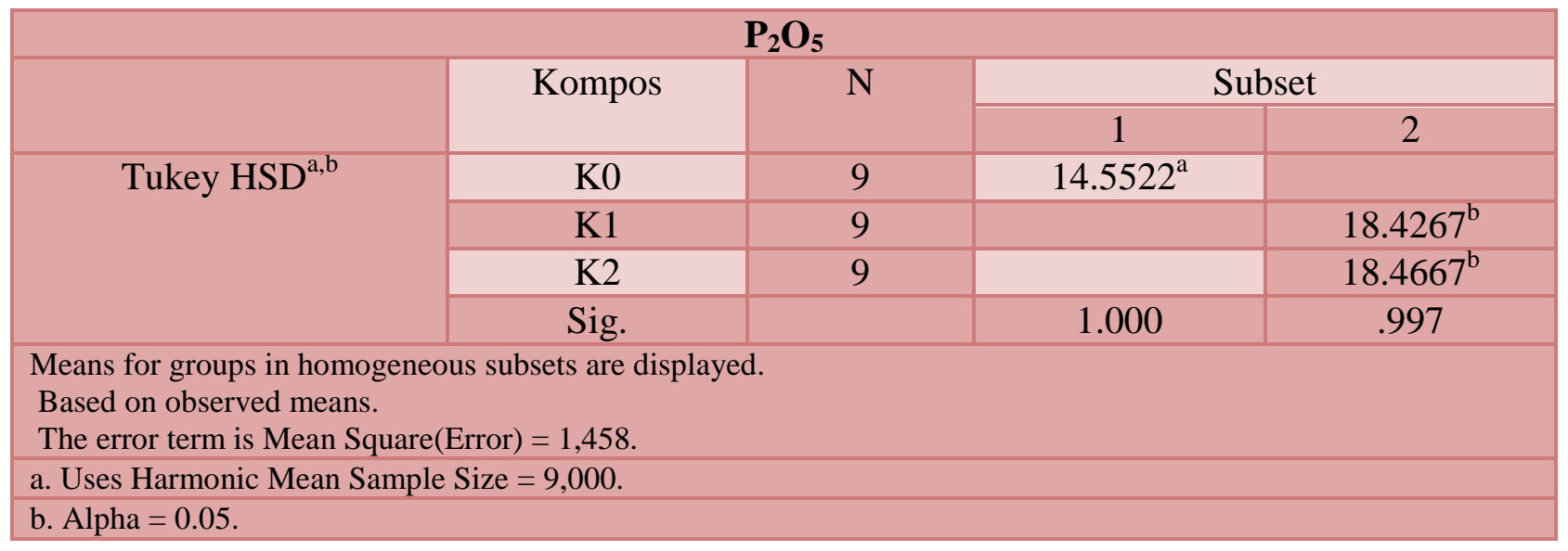




\section{Chart.1}

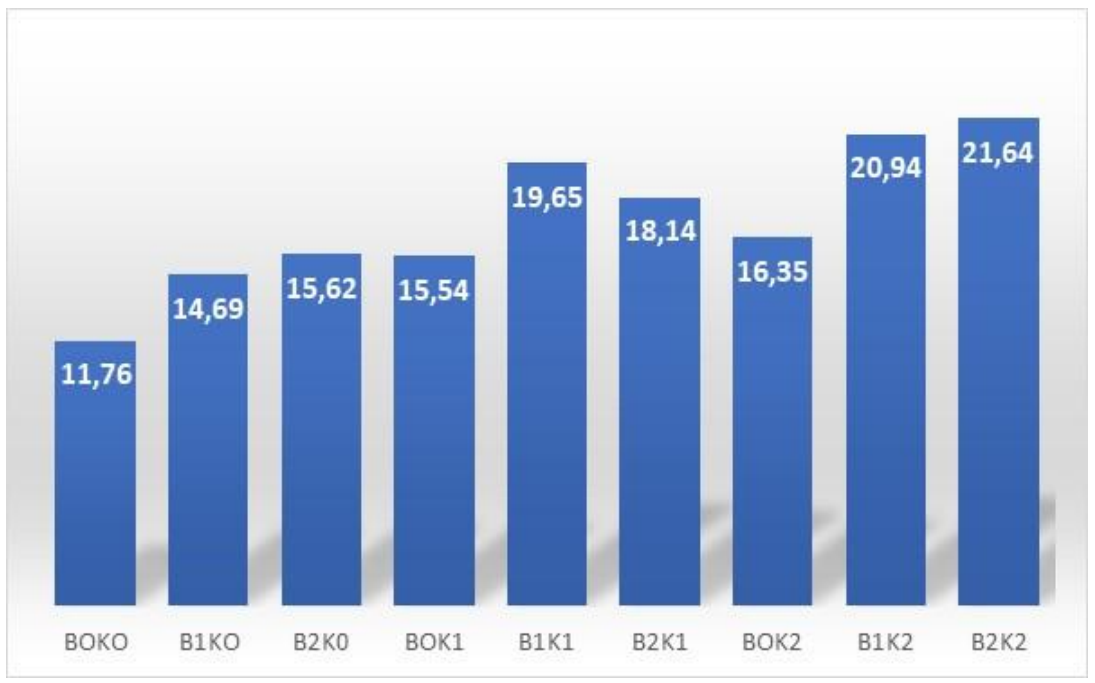

Compost is able to create a level of complexity of plant nutrients from organic matter that has been decomposed so that it is easy to be absorbed by the roots (Hansen, 2017).

The combination of biochar can be alkaline, especially when synthesized under the right conditions and also have basic components (Ca, $\mathrm{Mg}$ and $\mathrm{K}$ ) which of course can contribute both to neutralizing acidity in soil and can reduce the solubility of toxic hazardous metals such as aluminium (Gruba \& Mulder, 2008).

The relationship between the administration of Biochar and cocoa leaf waste on the dynamics of the nutrient Magnesium (Mg)

Preliminary research data indicate that magnesium is in the moderate range with a value of $1.98 \mathrm{me} / 100 \mathrm{~g}$. Magnesium plays an important role in the transport of phosphorus in plant cells, especially during seed formation in seed-producing plants, as well as in its role in photosynthetic activity which will cause chlorosis if its levels are lacking in plants. The combination of cocoa husk Biochar and cocoa leaf waste compost has a significant effect (Ginting et al., 2013) stated that excess magnesium exchanged in unbalanced soil adsorption complexes can cause deterioration of physiological characteristics in roots and can lead to decreased crop production.

The relationship between the provision of Biochar and cocoa leaf waste on the dynamics of the Potassium (K) nutrient

The results of preliminary observations at the research site showed that the element Potassium (K) before application showed a value of 0.16 me / $100 \mathrm{~g}$. Based on observations after application, it showed that there was a significant increase with the addition of $12 \mathrm{~kg}$ of cocoa waste compost ${ }^{-1}$ combined with 6 plants- 1 cocoa husk biochar. It is suspected that with the right combination it will make changes in the value of soil potassium which is able to contribute to the soil states that the presence of $\mathrm{Ca} 2+$ and $\mathrm{Mg} 2+$ ions can compete with $\mathrm{K}+$ in the soil adsorption complex so that it can affect the availability of K in the soil. (Supriyadi, 2009)

The relationship between the provision of Biochar and cocoa leaf waste on the dynamics of Phosphorus (P) nutrients

From the results of the Tukey test analysis showed a significant effect on the application 
of biochar and compost at all levels of treatment, Biochar derived from cocoa shell waste which is high in lignin and cellulose and phosphorus is not easy to wash even though the biochar is made at high temperatures, this is in accordance with the results of the study. (Iskandar \& Rofiatin, 2017) and (Prayogo, 2012) states that the elements of Phosphorus and potassium do not evaporate during the combustion process in contrast to Nitrogen and Sulfur.

The results showed that the combination of cocoa rind Biochar and fermented cocoa leaf waste had an effect on increasing calcium $(\mathrm{Ca})$ by 9.23 . Magnesium 1.66 and for the element Potassium had no significant effect on the interaction of the combination of cocoa husk biochar and fermented cocoa leaf waste, but gave a very significant effect on the administration of biochar $12 \mathrm{~kg} \mathrm{plant}^{-1}$.

The application of the combination of biochar and compost has a significant effect on increasing the phosphorus value, which is directly proportional to the number of combination treatments of biochar and cocoa waste compost.

\section{References}

Alibasyah, M. R., \& Karim, A. (2013). Degradasi Lahan Akibat Erosi pada Areal Pertanian di Kecamatan Lembah Seulawah Kabupaten Aceh Besar. Jurnal Manajemen Sumberdaya Lahan, 2(3), 240-249.

Basir, M., Kadekoh, I., \& Thaha, A. R. (2016). Potensi biochar sekam padi terhadap perubahan $\mathrm{ph}$, ktk, c organik dan $\mathrm{p}$ tersedia pada tanah sawah inceptisol Potency of Rice Husk Biochar on ModifyingSoil pH, CEC, C-Organic and Available $\mathrm{P}$ in Wetland Rice of Inceptisols. 23(2), 101-109.

Ginting, E. N., Sutandi, A., Nugroho, B., \&
Indriyati, L. T. (2013). Rasio dan kejenuhan hara $\mathrm{k}$, ca, mg di dalam tanah untuk tanaman kelapa sawit (Elaeis guineensis Jacq). Jurnal Ilmu Tanah Dan Lingkungan, 15(2), 60. https://doi.org/10.29244/jitl.15.2.60-65

Gruba, P., \& Mulder, J. (2008). Relationship between Aluminum in Soils and Soil Water in Mineral Horizons of a Range of Acid Forest Soils. Soil Science Society of America Journal, 72(4), 1150-1157. https://doi.org/10.2136/sssaj2007.0041

Hansen, I. J. (2017). Pengaruh pemberian beberapa dosis kompos kult buah kakao dan dolomit terhadap pertumbuhan bibit kakao (Theobroma cacao L.) di media ultisol. Jurnal Agroteknologi, $\quad 8(1), \quad 29$. https://doi.org/10.24014/ja.v8i1.3871

Juarsah, I., Yustika, R. D., \& Abdurachman, A. (2009). Pengendalian erosi dan kahat bahan organik tanah pada lahan kering berlereng mendukung produksi pangan nasional. Prosiding Seminar Nasional Dan Dialog Sumberdaya Lahan Pertanian. Bogor, 18-20 November 2008, 249-267.

Kamelia, M., \& Fathurohman, F. (2017). Pemanfaatan kulit buah kakao fermentasi sebagai alternatif bahan pakan nabati serta pengaruhnya terhadap pertumbuhan ternak entok (Cairina muschata). Biosfer: Jurnal Tadris Biologi, 8(1), 66-77. https://doi.org/10.24042/biosf.v8i1.126 4.

Nurida, Neneng Laela. (2014). Potensi Pemanfaatan Biochar untuk Rehabilitasi Lahan Kering di Indonesia Potency of Utilizing Biochar for Dryland Rehabilitation in Indonesia. 57-68.

Nurida, N L, \& Sutono, A. R. (2012). Sifat tanah terdegradasi dan peningkatan hasil jagung pada typic kanhapludults 
lampung. 12(1), 69-74.

Nurida, Neneng Laela. (2017). Potensi Pemanfaatan Biochar untuk Rehabilitasi Lahan Kering di Indonesia. Potensi Pemanfaatan Biochar Untuk Rehabilitasi Lahan Kering Di Indonesia, 8(3), 57-68. https://doi.org/10.2018/jsdl.v8i3.6503

Rafeie Jahed, R., Hosseini, S. M., \& Kooch, Y. (2014). The effect of natural and planted forest stands on soil fertility in the Hyrcanian region, Iran Biodiversitas, 15(2), 206-214. https://doi.org/10.13057/biodiv/d15021 3.

Six, J., Bossuyt, H., Degryze, S., \& Denef, K.
(2004). A history of research on the link between (micro)aggregates, soil biota, and soil organic matter dynamics. Soil and Tillage Research, $79(1)$, 7-31. https://doi.org/10.1016/j.still.2004.03.0 08

Supriyadi, S. (2009). Status unsur-unsur basa $(\mathrm{Ca} 2+, \mathrm{Mg} 2+, \mathrm{K}+$, and $\mathrm{Na}+) \mathrm{DI}$ LAHAN KERING MADURA Slamet. Agrovigor, 2(1979 5777), 35-41.

Winarso, S. (2005). Kesuburan Tanah; Dasar Kesehatan dan Kualitas Tanah. Gava Media. Yogyakarta.

\section{How to cite this article:}

Iinnaninengseh, Yunus Musa, Rismaneswati and Rosmana, A. 2021. Change of Land Quality with the Introduction of the Biochar Combination and Cocoa Waste Compost. Int.J.Curr.Microbiol.App.Sci. 10(09): 464-472. doi: https://doi.org/10.20546/ijcmas.2021.1009.054 